\title{
Mechanical behavior and water absorption in sisal/glass hybrid composites
}

\author{
Camila Cruz da Silva ${ }^{2}$, Raimundo Carlos Silverio Freire Júnior ${ }^{1}$, \\ Elmo Thiago Lins Cöuras Ford ${ }^{1}$, Camilla Medeiros Dantas ${ }^{2}$, \\ Jayna Kátia Dionisio dos Santos ${ }^{3}$, Eve Maria Freire de Aquino ${ }^{1}$
}

\footnotetext{
${ }^{1}$ Federal University of Rio Grande do Norte - UFRN- PPGEM, Av. Lagoa Nova, S/N, Natal, Rio Grande do Norte, Brazil.

${ }^{2}$ Federal Institute of Science and Technology of Bahia, Vitória da Conquista, Bahia, Brazil.

${ }^{3}$ Federal Institute of Science Education and Technology of Ceara, Jaguaribe, Ceará, Brazil.

e-mail: elmocouras@hotmail.com
}

\section{ABSTRACT}

This study aimed to assess the effect of hybridization on thermomechanical properties and water absorption of composite materials, by introducing sisal fiber tissue into the material. To that end, two composite material plates were manufactured, the first with five layers of E-glass reinforcement mat and the second with three layers of E-glass fiber interspersed with two layers of sisal fibers, both used as an orthophthalic polyester resin matrix. The material was then submitted to tensile, three-point bending and water absorption tests. It was observed that hybridization causes a change in both the final strength and stiffness of the material.

Keywords: Composite material, water absorption, mechanical properties, natural fibers.

\section{INTRODUÇÃO}

Due to the search for new technologies and materials, studies on polymer composites have been gaining ground in a number of industrial sectors, with the aim of reducing costs and the damage caused to the environment. In this context, several researchers [1-7], have applied natural fibers with reinforcement in composites, in order to decrease the industrial use of synthetic fibers. Unfortunately, the development of composites made solely with natural fibers significantly reduces their mechanical properties compared to those made with synthetic fibers. Thus, hybridization could be an alternative to using natural fibers without a significant loss of strength and stiffness [8-11].

Another characteristic of natural fibers is their ability to absorb water (hydrophilic) [12-15]. Thus, it is always important to assess the effects of this phenomenon on the final mechanical performance of the material.

Among the natural fibers reported in the literature, such as pineapple, jute, coconut, curauá, sisal, rami [1621], it was decided to assess the use of sisal fiber due to its extensive production in Brazil (254,427 t/year (IBGE) (Brazilian Institute of Geography and Statistics), biodegradability, recyclability, low density, nonabrasiveness, low energy consumption, low cost and ready availability in the market. There are several literature references [22-25], showing that sisal fiber can be used as reinforcement with both thermoplastic (Polyethylene, PVC, Polypropylene) and thermoset matrices (Polyester and Epoxy). The orthophthalic Polyester Resin (UPR) was used as a matrix because of its low cost and ease of lamination.

Thus, the objective of this research was to study the mechanical properties of tensile strength and three-point bending of two laminates in the dry and wet state. The E-glass mat fiber laminate has a stacking sequence consisting of three E-glass fibers, interspersed with two layers of sisal fibers. After mechanical properties were determined, microscopic analyses were conducted in the region of the fracture in order to better understand the absorption and fracture mechanisms. 


\section{MATERIALS AND METHODS}

\subsection{Manufacturins Process}

Unsaturated orthophthalic polyester resin, pre-accelerated and catalyzed with $1 \%$ by weight of ethyl methyl ketone (MEK-P), was used to manufacture the composite materials. The curing process occurred at ambient temperature.

The reinforcements used were E-glass fiber mats (GM) with grammage of $450 \mathrm{~g} / \mathrm{m}^{2}$ and sisal fiber tissues with grammage of $800 \mathrm{~g} / \mathrm{cm}^{2}$, manufactured on a hand loom. The sisal fibers were arranged in strands with approximate weight of $1.7 \mathrm{~g}$, first along the warp and then the weft. At the end of the process a bidirectional sisal tissue (ST) was obtained, as shown in Figure 1. Next, the composite laminates were manufactured using the hand lay-up technique. The stacking sequence used produced two 5-layer laminates, one with all layersmade of fiberglass mat $[\mathrm{GM}]^{5}$ and a volumetric density of $1.51 \mathrm{~g} / \mathrm{cm}^{3}$, and the other a hybrid laminate with three layers of fiberglass interspersed with two layers of sisal tissue [GM/ST/GM/ST/GM] and volumetric density of $1.17 \mathrm{~g} / \mathrm{cm}^{3}$. The volumetric density was obtained using the ASTM D792 [26].

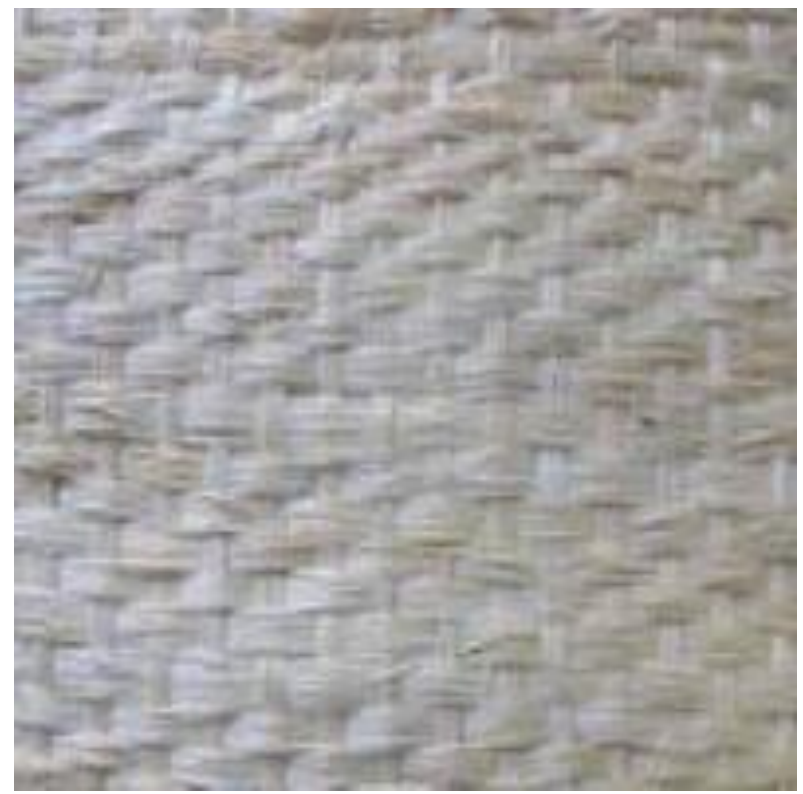

Figure 1: Sisal Tissue (ST).

\subsection{Tensile and Three-Point Bending Tests}

Tensile and three-point bending tests were conducted using a Shimadzu AG-X universal testing machine. The test procedure and test specimen dimensions were obtained from ASTM D3039 [27] and D790 [28], for the tensile and bending tests, respectively. For each case assessed, at least five test specimens were used, with dimensions according to their respective guidelines. Maximum strength, modulus of elastic and strain were analyzed for all the test specimens.

\subsection{Water Absorption Test}

The water absorption tests were conducted in distilled water and based on ASTM D570 [29]. For each laminate, five test specimens measuring $25 \mathrm{~mm}$ x $76 \mathrm{~mm}$ were used. The edges of the samples are sealed with resin to avoid capillarity of water.

The test specimens were cut, measured and weighed before being immersed in water at ambient temperature. Since absorption is greater at the start of the process, the samples were weighed in the first $12 \mathrm{~h}$ and after $24 \mathrm{~h}$ measures were taken every week. The material was considered saturated, that is, could not absorb more water, when absorption did not exceed the previous measure by $1 \%$ or when the absorbed weight was less than $0.005 \mathrm{~g}$ between weighings.

It is important to underscore that the tensile and three-point bending tests were conducted in both dry and saturated samples for both laminates. 
In addition, we analyzed the value of the diffusion coefficient (D) and coefficient of Fick, this parameter is the absorption rate, ie in this case the speed that the water is absorbed by the material, so that a material with high diffusivity coefficient will absorb large amounts of water quickly, something undesirable in most applications, while a material with a low value of diffusion coefficient takes a long time to absorb water even absorb large quantities at the end of the test. Equation 1 [30] then refers to the calculation of the Fick coefficient $\left(\mathrm{mm}^{2} / \mathrm{s}\right)$.

$$
\mathrm{D}=\pi\left(\frac{\mathrm{h}}{4 \mathrm{M}_{\mathrm{m}}}\right)^{2}\left(\frac{\mathrm{M}_{2}-\mathrm{M}_{1}}{\sqrt{\mathrm{t}_{2}}-\sqrt{\mathrm{t}_{1}}}\right)^{2}
$$

Where $\mathrm{D}$ is the coefficient of Fick, $\mathrm{h}$ is the mean thickness of sample (mm) $\mathrm{mm}$ and the maximum moisture absorbed t2, t1, M2 and M1 are time points (s) and humidity respectively obtained in the linear region (initial) humidity test.

From Fick obtaining the coefficient may be constructed to theoretical curve of water absorption $(\mathrm{G})$, represented in Equation 2 [30]. Where $t$ is the time in seconds, and D shows the diffusion coefficient.

$$
G(t)=1-\exp \left[-7,3\left(\frac{D \cdot t}{h^{2}}\right)^{0,75}\right]
$$

\section{RESULTS AND DISCUSSIONS}

\subsection{Mechanical Tests in the Dry State}

The results obtained for the tensile test showed that the hybrid laminate (SGH) exhibited greater dispersion than that of the E-glass fiber mats (GM), as depicted in figure 2. Two factors could explain this situation: the first is the fact that sisal fiber had greater dispersion in both strength and stiffness, causing variations in the mechanical properties of the laminates containing this fiber, while the second is linked to the hybridization of the composite, given that the abrupt change in material between laminates increases interlaminar stress. These factors are also observed by other authors [31].
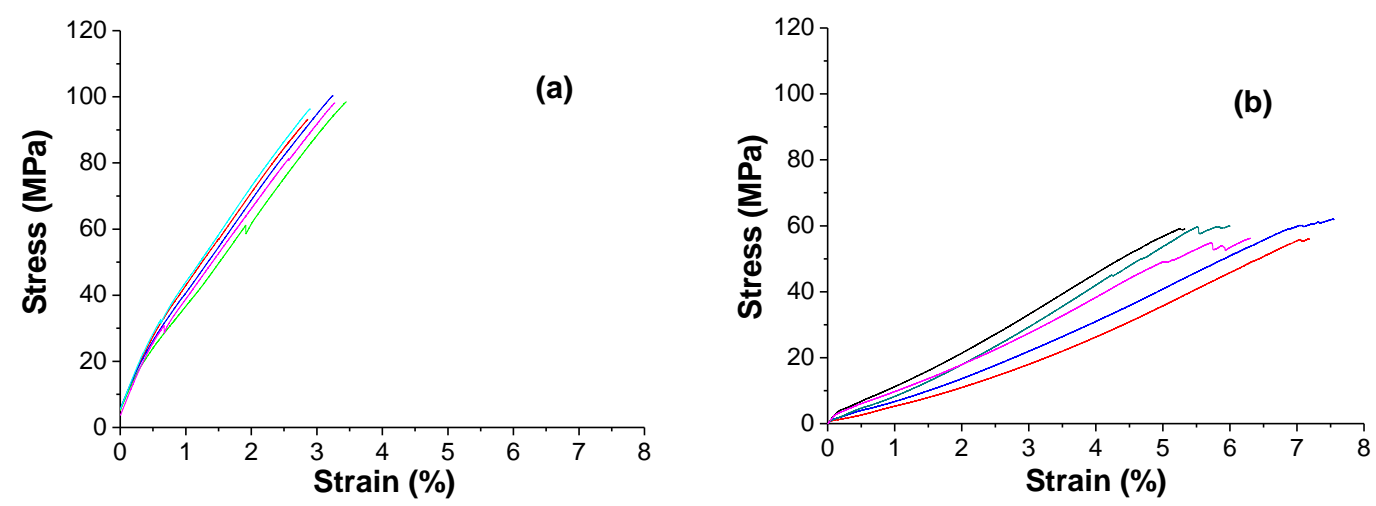

Figure 2: Stress-Strain curve Uniaxial tensile strength of laminates GM (a) and SGH (b) in the dry state.

With respect to mean mechanical property values (Table 1), introducing sisal tissues reduced strength by $36.18 \mathrm{MPa}(37 \%)$ and stiffness by $1.44 \mathrm{GPa}(52.6 \%)$ from laminate GM to hybrid laminate SGH. These results were expected, since the addition of a natural fiber (sisal fiber in our case) instead of a glass fiber decreased the mechanical properties of the composite [32]. 
Table 1: Mechanical properties obtained in tensile test in dry state.

\begin{tabular}{ccc}
\hline Mechanical Properties & GM & SGH \\
\hline Ultimate Stress $(\mathbf{M P a})$ & 97.33 & 61.15 \\
\hline Elastic Modulus $(\mathbf{G P a})$ & 2.74 & 1.3 \\
\hline Breaking Strain (\%) & 3.14 & 6.59 \\
\hline
\end{tabular}

The sisal fiber presented a density less than the fiberglass $\left(\rho_{\text {sisal }}=1.26 \mathrm{~g} / \mathrm{cm}^{3}\right.$ and $\left.\rho_{\text {glass }}=2.68 \mathrm{~g} / \mathrm{cm}^{3}\right)$, and the density of the composites presented in item 2.1 was $1.17 \mathrm{~g} / \mathrm{cm}^{3}$ for SGH and $1.51 \mathrm{~g} / \mathrm{cm}^{3}$ for GM. Considering the density of these materials in the analyses of their mechanical properties, it can be observed that these properties also decline from the GM to the SGH (Figure 3).
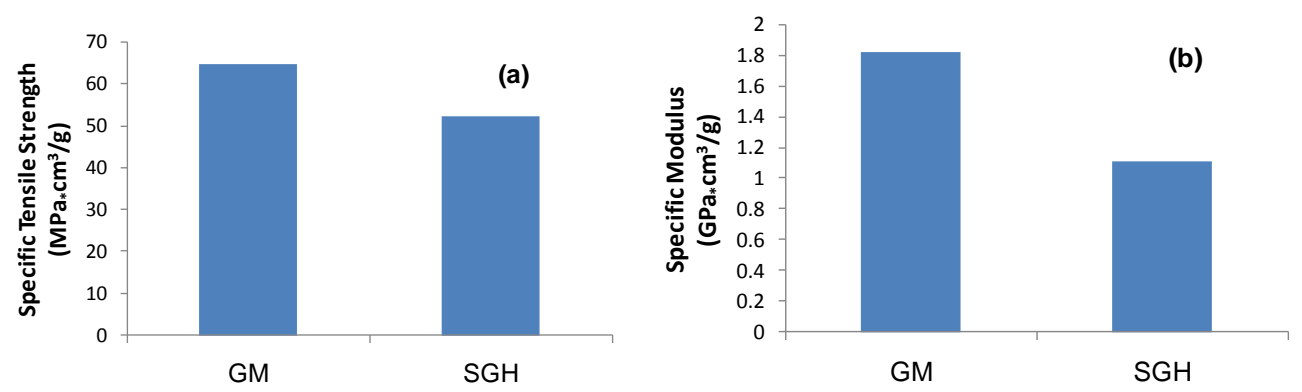

Figure 3: (a) Specific ultimate tensile strength and (b) specific tensile modulus in laminates in the dry state.

However, this decrease is lower than that obtained disregarding the density of the material, in which there was a difference in strength of $14.6 \%$ (versus $37.2 \%$ ) and stiffness of $29.2 \%$ (versus $52.6 \%$ ). This result demonstrates that, despite the loss of strength owing to the use of a natural fiber, the feasibility of using this hybrid composite is justified if the aim is lower cost and lighter weight [33].

Data dispersion on bending tests (Figure 4), was smaller than in tensile test. (Figure 2). The mean mechanical property values (Table 2) show that hybridization interferes more in the final strength of the composite than stiffness, with a $51.53 \%$ and $21.67 \%$ reduction respectively, different from what occurred with these materials in tensile tests, where a greater decrease was obtained for stiffness than for strength.
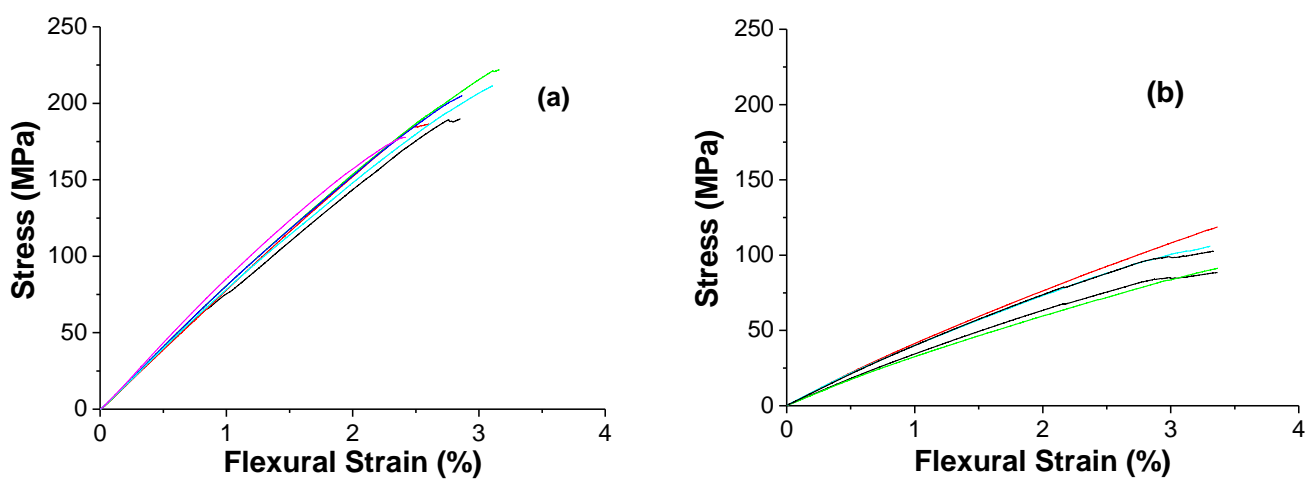

Figure 4: Stress-Flexural strain curve for Three-point bending test of laminates GM (a) and SGH (b) in the dry state. 
Table 2: Mechanical properties obtained in bending test in dry state.

\begin{tabular}{ccc}
\hline Mechanical Properties & GM & SGH \\
\hline Ultimate Stress (MPa) & 198.76 & 96.32 \\
\hline Flexural Elastic Modulus (GPa) & 6.98 & 5.51 \\
\hline Maximum Flexural strain (\%) & 2.85 & 9.77 \\
\hline
\end{tabular}

When we consider the density of both materials, hybrid composite SGH exhibited practically the same stiffness as composite GM, since the difference between the two was $0.08 \mathrm{GPa}$, demonstrating once again the feasibility of the hybrid composite. These results can be better visualized in Figure 5, which contains specific stress and stiffness values of the materials for three-point bending tests.
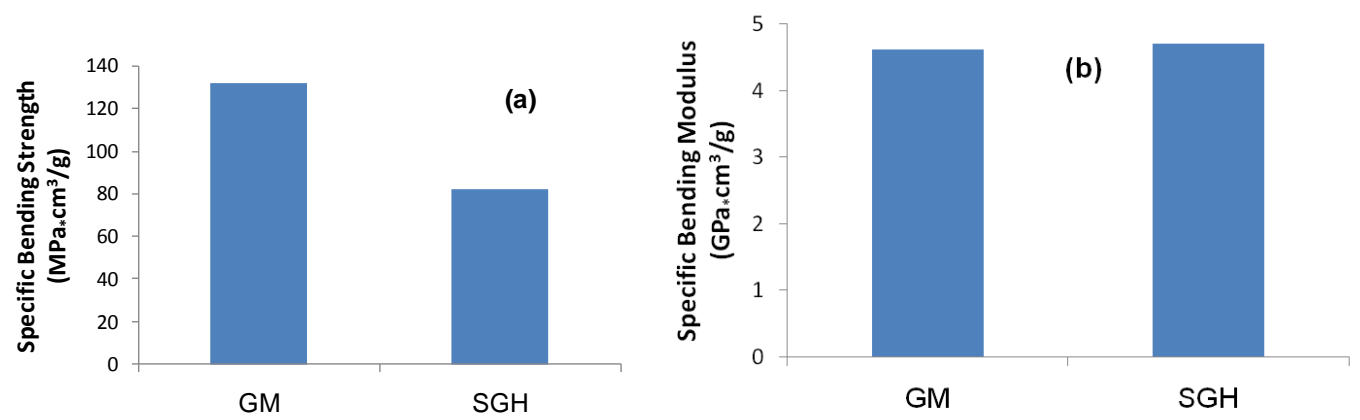

Figure 5: Mechanical properties to bending tests in the dry state.

\subsection{Water Absorption Test}

Figure 6 shows that absorption behavior changes; when hybridization is performed, both laminates initially showed linear behavior, with a decline in the absorption rate (Fick's behavior) and a different saturation time. Another factor observed is that sisal fiber is hydrophilic, with $5 \%$ absorption for the hybrid laminate.
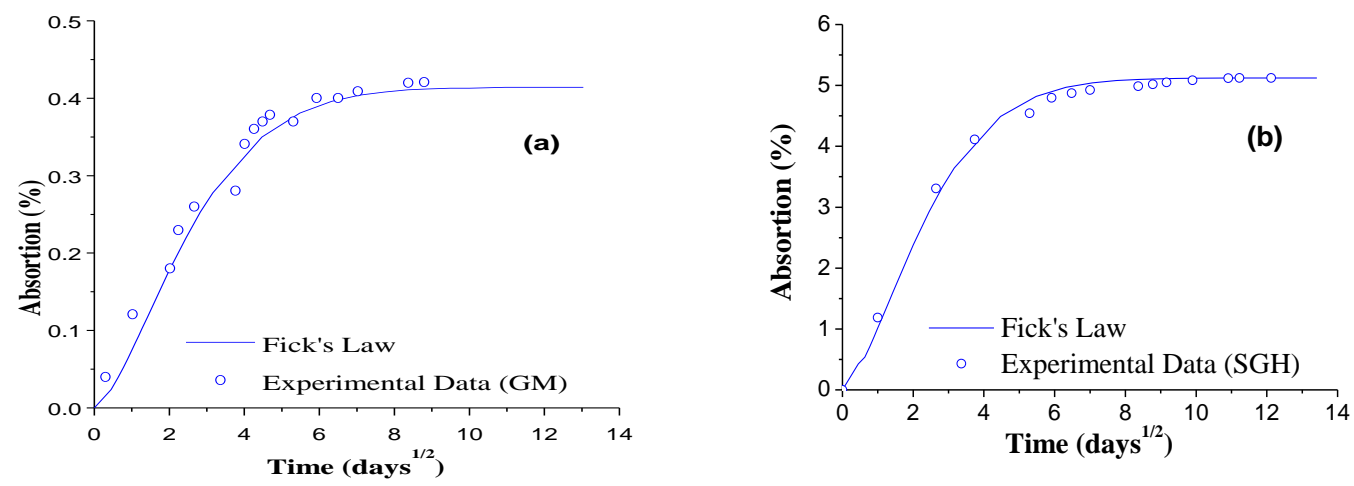

Figure 6: Percentage absorption versus immersion time to GM (a) and SGH (b).

As expected, the hydrophilic characteristic of sisal fiber caused the hybrid composite (SGH) to absorb a larger amount faster than GM (Table 3), where the diffusivity was $1.51 \times 10^{-6} \mathrm{~mm}^{2} / \mathrm{s}$ for laminate GM and $6.64 \times 10^{-6} \mathrm{~mm}^{2} / \mathrm{s}$ for laminate $\mathrm{SGH}[34]$. 
Table 3: Results obtained in the moisture absorption test.

\begin{tabular}{cccc}
\hline Materials & $\begin{array}{c}\text { Maximum Absor- } \\
\text { ption (\%) }\end{array}$ & $\begin{array}{c}\text { Time of Absorption } \\
\text { (days) }\end{array}$ & Diffusivity $\left(\mathrm{mm}^{2} / \mathbf{s}\right)$ \\
\hline $\boldsymbol{G M}$ & 0.41 & 49 & $1.51 \times 10^{-6}$ \\
\hline $\boldsymbol{S G H}$ & 4.99 & 147 & $6.64 \times 10^{-6}$ \\
\hline
\end{tabular}

\subsection{Mechanical Tests in the Saturated State}

After a period of saturation, tensile tests showed that the laminates tend toward linearization, and that the Elastic of modulus laminate SGH (Figure 7b) declines in relation to laminate GM (Figure 7a). There was also a reduction in the tensile strength limit (Table 4), where loss of strength was $53.4 \%$ compared to the GM material under the same condition, while stiffness decreased by $51.9 \%$.
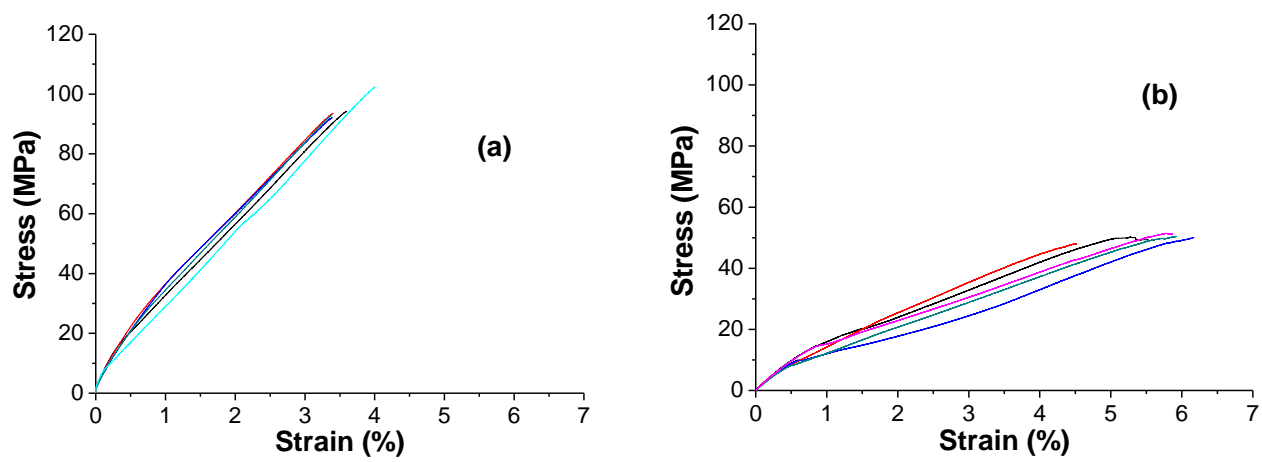

Figure 7: Stress-Strain curve uniaxial tensile strength of laminates GM (a) and SGH (b) in the wet state.

Table 4: Mechanical properties obtained in tensile test in wet state.

\begin{tabular}{ccc}
\hline Mechanical Properties & GM & SGH \\
\hline Ultimate Stress $(\mathbf{M P a})$ & 95.05 & 44.02 \\
\hline Elastic Modulus $(\mathbf{G P a})$ & 2.31 & 1.11 \\
\hline Maximum Strain (\%) & 3.86 & 5.48 \\
\hline
\end{tabular}

The flexion tests (Figure 8) it was verified that the moisture influenced significantly the mechanical properties of both materials (see also Tables 2 and 5) than the observed in tensile testing, where the highest decrease in resistance was found for GM laminate, with $23.5 \%$ loss in flexion while tensile was only $2.5 \%$. Whereas the SGH laminate has $30.6 \%$ for flexion loss and $28 \%$ for tensile loss, behavior also observed by other authors [34]. 

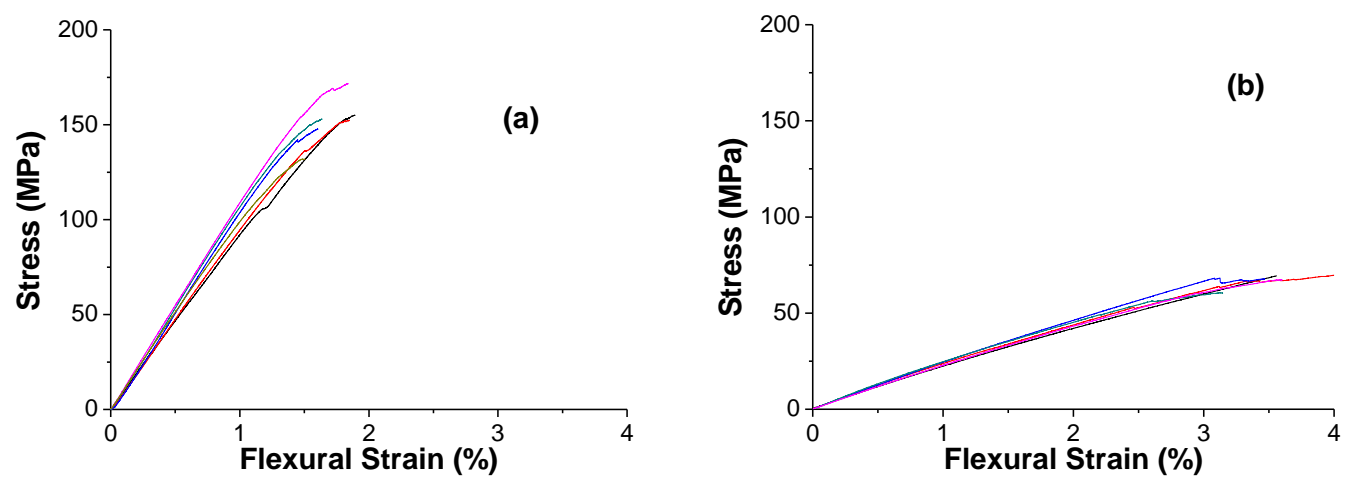

Figure 8: Stress-Flexural strain curve for three-point bending test of laminates GM (a) and SGH (b) in the dry state.

Table 5: Mechanical properties obtained in bending test in wet state.

\begin{tabular}{ccc}
\hline Mechanical Properties & GM & SGH \\
\hline Ultimate Stress (MPa) & 151.98 & 66.82 \\
\hline Flexural Elastic Modulus (GPa) & 5.73 & 4.1 \\
\hline Maximum Flexural strain (\%) & 2.65 & 7.07 \\
\hline
\end{tabular}

A scanning electron microscope (SEM) was utilized in order to better understand the decrease in strength and elastic modulus, in which was verified a good fiber/matrix adhesion in the composites in dry state for all fractured region (Figure 9), but for the materials tested in wet state showed a large non-adherence at fiber/matrix throughout the fracture region (Figures 10 and 11), this behavior was observed more frequently in sisal fiber, which probably occurred due to the hydrophilic nature of this fiber [14] causing large absorbing of water by capillarity and facilitating its accumulation in the fiber/matrix interface and considerably decreasing the hybrid composite resistance [21].

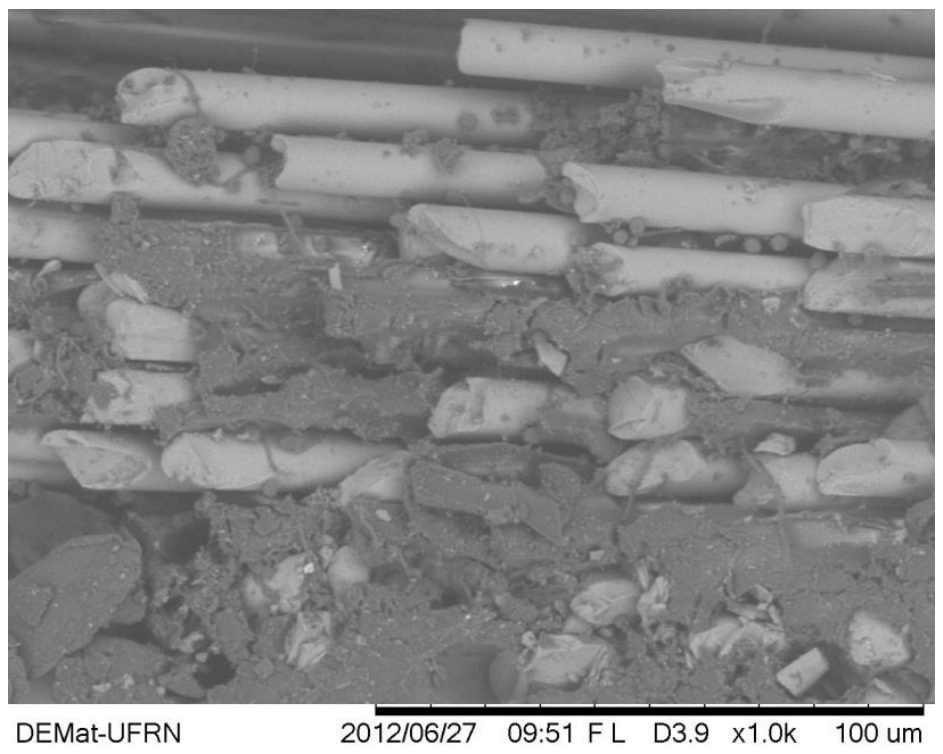

Figure 9: Matrix fiber debonding in laminate SGH. 


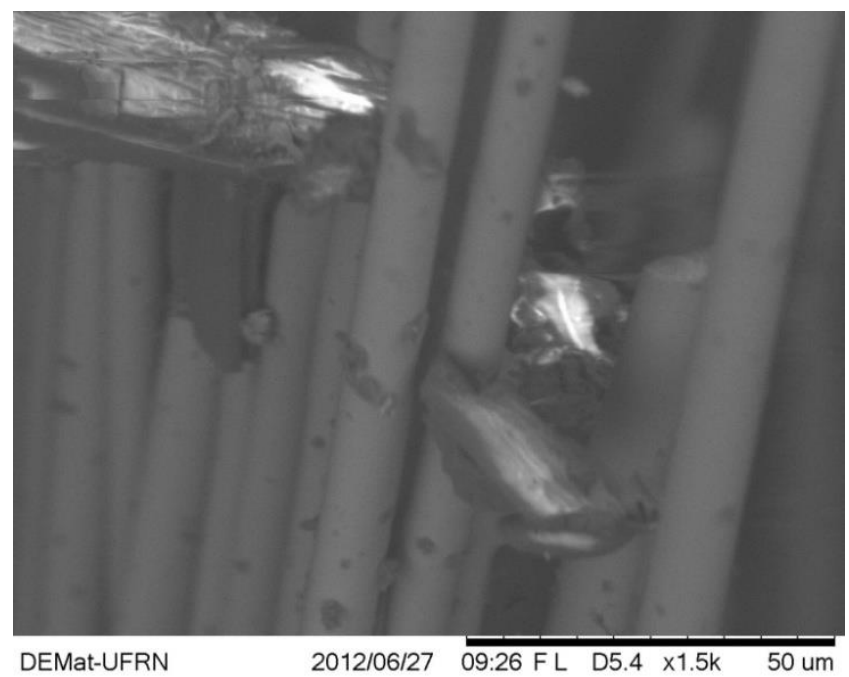

Figure 10: Laminate SGH region of the final fracture.

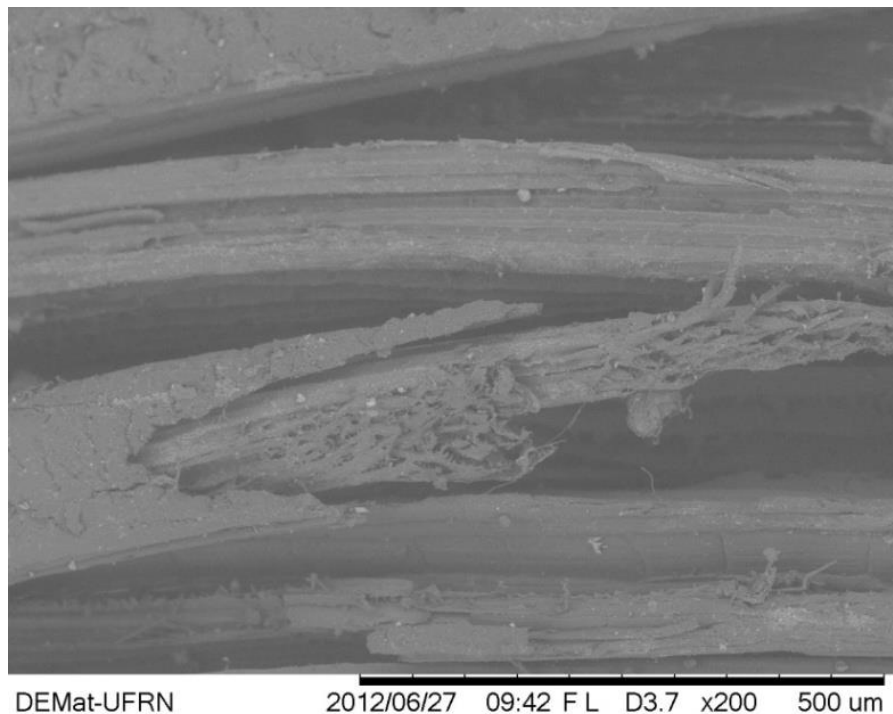

Figure 11: Non-adherence in sisal fiber (SGH) in wet state.

\section{CONCLUSION}

Based on the presented results, it may conclude that:

- Sisal fiber woven fabric may be used as an alternative to glass fiber mats for composite hybridization, especially if it is important the density relation with the resistance;

- The hybrid composite on sisal fiber base has a large water absorption compared to reinforced composite with glass fiber and this absorption occurs rapidly as demonstrated by the Fick coefficient;

- Due to natural fibers capillary to water is deposited easily and in large quantities in the fiber/matrix interface significantly reducing the mechanical resistance of these materials, due to this, it may be assert that these materials are not suitable for applications with moist atmosphere.

\section{ACKNOWLEDGMENTS}

The authors thank the research grants provided by CAPES and CNPq. 


\section{BIBLIOGRAPHY}

[1] KENGKHETKIT, N., AMORNSAKCHAI, T. "Utilization of pineapple leaf waste for plastic reinforcement: 1. A novel extraction method for short pineapple leaf fibre", Industrial Crops and Products, v.40, pp. 55-61, 2012.

[2] MONTEIRO, S. N, AQUinO, R. C. M. P., LOPES, F. P. D., et al., "Comportamento Mecânico E Características Estruturais De Compósitos Poliméricos Reforçados Com Fibras Contínuas E Alinhadas De Curauá”, Matéria (R.J), v. 11, n. 3, pp. 197-203, 2006.

[3] PIMENTA, M. T. B., CARVALHO, A. J. F., VILASECA, F., et al., "Soda-treated Sisal/Polypropylene Composites", J Polym Environ, v. 16, pp.35-39, 2008.

[4] SANGTHONL, S., PONGPRAYOOH, T., YANUMET, N. "Mechanical property improvement of unsaturated polyester composite reinforced with admicellar-treated sisal fibers", Composites Part A, Applied Science and Manufacturing, v. 40, pp. 687-694, 2009.

[5] BLEDZKI, A. K., ZHANG, W., CHATE, A. Natural-fibre-reinforced polyurethane microfoams. Composites", Science and Technology, v. 61, pp. 2405-2411, 2011.

[6] OKSMAN, K., WALLSTROM, L., BERGLUND, L. A., et al., "Morphology and Mechanical Properties of Unidirectional Sisal-Epoxy Composites", Journal of Applied Polymer Science, v. 84, pp. 2358-2365, 2002.

[7] SEN, I., ARAL, A., SEKI, Y., et al., "Variations of mechanical properties of jute/polyester composite aged in various media", Journal of Composite Materials, v. 46, pp. 2219-2225, 2012.

[8] RODRIGUES, L. P. S. Efeitos do Envelhecimento Ambiental Acelerado em Compósitos Poliméricos, Dissertação de Mestrado, UFRN, Natal, Brasil, 2007.

[9] IDICULA, M., MALHOTRA, S. K., JOSEPH, K., et al., "Dynamic Mechanical Analysis Of Randomly Oriented Intimately Mixed Short Banana/Sisal Hybrid Fibre Reinforced Polyester Composites", Composites Science And Technology, v. 65, pp. 1077-1087, 2005.

[10] VENKATESHWARAN, N., ELAYAPERUMAL, A. "Mechanical and water absorption behaviour of banana/sisal reinforced hybrid composites”, Materials and Design, v. 32, pp. 4017-4021, 2011.

[11] CARVALHO, L. H., LADCHUMANANANDASIVAM, R., ALEXANDRE, M. E. O., et al., "Propriedade mecânicas de Compósitos Poliméricos Reforçados por Folhas do Abacaxi”, In: ISNAPOL, São Pedro, SP, 2004.

[12] TSENOGLOU, C., PAVLIDOU, S., PAPASPYRIDES, C. D. "Evaluation of interfacial relaxati on due to water absorption in fiber-polymer composites", Composites Science and Technology, v. 66, pp. 28552864, 2006.

[13] KIM, H. J AND SEO, W. "Effect of water absorption fatigue on mechanical properties of sisal textilereinforced composites", International Journal of Fatigue, v. 28, pp. 1307-1314, 2006.

[14] CHOW, C. P. L., XING, X. S., L. I, R. K. Y. "Moisture Absorption Studies Of Sisal Fibre Reinforced Polypropylene Composites”, Composites Science And Technology, v. 67, pp. 306-313, 2007.

[15] SPRINGER, A. C., SPRINGER, G. S., SANDERS, B. A. "Moisture Absorption of Polyester-E Glass Composites", Journal of Composite Materials, v. 14, pp. 142-153, 1980.

[16] JOSEPH, P. V. "Efect of processing variables on themomechanical properties of sisal-fiber-reinforced polypropylene composites", Composites Science and Technology, v. 59, pp. 1625-1640, 1999.

[17] JOSEPH, PV. "Eviromental Effects on the Degradation Behavior of Sisal Fibre Reinforced Polypropylene Composites”, Composites Science and Tecnology, v.60, n.10, pp. 1357-1372, 2002.

[18] NUNNA, S., CHANDRA, P. R., SHRIVASTAVA, S., et al., "A review on mechanical behavior of natural fiber based hybrid composites”, Journal of Reinforced Plastics and Composites, v. 31, pp. 759-769, 2012.

[19] GODA, K., SREEKALA, M.S., GOMES, A., et al., "Improvement of plant based natural fibers for toughen in green composites: Effect of load application during mercerization of ramie fibers", Composites: Part A, v. 37, pp. 2213-2220, 2006.

[20] YU, T., REN, J., LI, S., et al., "Effect of fiber surface-treatments on the properties of poly(lactic acid)/ramie composites", Composites Part A: Applied Science and Manufacturing, v. 41, pp. 499-505, 2010. 
[21] MISHRA, S., MISRA, M., TRIPATHY, S.S., et al., "Potentiality of pineapple leaf fibre as reinforcement in PALF-polyester composite: Surface modification and mechanical performance", Journal of Reinforced Plastics and Composites, v. 20, pp. 321-334, 2001.

[22] RONG, M. Z., ZHANG, M. Q., LIU, Y., et al., "The effect of fiber treatment on the mechanical properties of unidirectional sisal-reinforced epoxy composites", Composites Science and Technology, v. 61, pp. 1437-1447, 2001.

[23] AHMAD, E. E. M., LUYT, A. S. "Effects of Organic Peroxide and Polymer Chain Structure on Mechanical and Dynamic Mechanical Propertiesof Sisal Fiber Reinforced Polyethylene Composites", Journal of Applied Polymer Science, v. 125, pp. 2216-2222, 2012.

[24] HASSAN, M. L; NADA, A. M. A. Utilization of Lignocellulosic Fibers in Molded Polyester Composites - Journal of Applied Polymer Science, vol. 87, pp. 653-660, 2013.

[25] NHLAPO, L. P., LUYT A. S. "Thermal And Mechanical Properties of LDPE/Sisal Fiber Composites Compatibilized with Functionalized Paraffin Waxes", Journal of Applied Polymer Science, v. 123, pp. 3627 3634, 2012.

[26] AMERICAN SOCIETY FOR TESTING AND MATERIALS D792. Standard Test Methods for Specific Gravity and Density of Plastics by Displacement. Philadelphia, 2014.

[27] AMERICAN SOCIETY FOR TESTING AND MATERIALS D3039. Standard test method for tensile properties of oriented fiber composites. Philadelphia, 2014.

[28] AMERICAN SOCIETY FOR TESTING AND MATERIALS D790. Standard Test Method for Flexural Properties of Unreinforced and Reinforced Plastics and Electrical Insulating Materials. Philadelphia, 2014.

[29] AMERICAN SOCIETY FOR TESTING AND MATERIALS D570. Standard Test Methods for Water Absorption of Plastics. Philadelphia, 2014.

[30] AMERICAN SOCIETY FOR TESTING AND MATERIALS D5229. Standard Test Methods for Moisture Absorption Properties and Equilibrium Conditioning of Polymer Matrix Composite Materials. Philadelphia, 2014.

[31] RATNA PRASAD, A.V., MOHANA RAO, K. "Mechanical properties of natural fibre reinforced polyester composites: Jowar, sisal and bamboo", Materials \& Design, v. 32, n. 8- 9, pp. 4658-4663, 2011.

[32] THAIS, H. D., SYDENSTRICKER, S., MOCHNAZ, S. C. A. "Pull-out and other evaluations in sisalreinforced polyester biocomposites", Polymer Testing, v. 22, n. 4, pp. 375-380, 2003.

[33] ASHISH KUMRE, R. S. RANA, R. P. "A Review on mechanical property of sisal glass fiber reinforced polymer composites”, Materials Today: Proceedings, v. 4, n. 2, pp. 3466-3476, 2017.

[34] SREEKUMAR, P.A, SELVIN P., KURUVILLA JOSEPH, G., et al., "Effect of fiber surface modification on the mechanical and water absorption characteristics of sisal/polyester composites fabricated by resin transfer molding", Composites Part A: Applied Science and Manufacturing, v. 40, n. 11, pp. 1777$1784,2009$. 